\title{
\begin{tabular}{l|l|l} 
& Jurnal Kependidikan Dasar & $\begin{array}{l}\text { Volume : } 2 \\
\text { Nomor :2 } \\
\text { Tahun :2017 }\end{array}$ \\
\end{tabular}
}

\section{Penggunaan Model Pembelajaran SAVI Untuk Meningkatkan Prestasi Belajar IPS Pada Siswa Kelas V SD Al Husna Kota Madiun}

\author{
Eka Nofri Ari Yanto \\ Dosen Prodi PGSD Universitas PGRI Madiun \\ ekanofri90@gmail.com
}

\begin{abstract}
ABSTRAK
Berdasarkan hasil observasi yang dilakukan peneliti di SD Al Husna (IFDS), diketahui bahwa proses pembelajaran di kelas $\mathrm{V}$ masih bersifat konvensional sehingga kurang mengembangkan pola pikir dan kreatifitas siswa. Terdapat beberapa guru khususnya pada mata pelajaran IPS kelas V hanya berceramah dan siswa hanya mendengarkan, mencatat dan menghafalkan materi. Penelitian ini bertujuan untuk meningkatkan prestasi belajar siswa khususnya pada mata pelajaran IPS kelas VA dengan menggunakan model pembelajaran SAVI. Penelitian ini menggunakan metode Penelitian Tindakan Kelas (PTK), prosedur penelitian yang digunakan berupa siklus yang terdiri dari empat tahap yaitu tahap perencanaan, pelaksanaan, observasi dan refleksi.Teknik pengumpulan data yang digunakan adalah tes kognitif dan alat pengumpulan data yang digunakan adalah instrumen soal dan lembar observasi.

Hasil analisis data yang diperoleh menunjukkan bahwa terjadi peningkatan pada hasil belajar yang berdampak pada prestasi belajar siswa.Hal ini dapat dilihat dari hasil presentase rata-rata pada siklus I yaitu 75\% yang artinya ada 15 dari 20 siswa yang tuntas. Terjadi peningkatan pada siklus yang ke II yaitu 80\% yang artinya ada 16 dari 20 siswa yang tuntas dalam pembelajaran. Pada siklus terakhir juga mengalami peningkatan yang signifikan dari siklus sebelumnya yaitu $90 \%$ yang artinya ada 18 dari 20 siswa yang tuntas pada siklus terkhir ini. Berdasarkan hasil penelitian, dapat disimpulkan bahwa implementasi model pembelajaran SAVI dapat meningkatkan prestasi belajar siswa pada mata pelajaran IPS kelas V SD Al Husna (IFDS).
\end{abstract}

Kata Kunci : Prestasi Belajar, IPS, Model Pembelajaran SAVI (Somatic, Auditory, Visualization, Intelectually) 


\section{ABSTRACT}

The result of observation in Al Husna Elementary School (IFDS) is learning process on 5th grade which is still conventional so student's mindset's development and creativity is less. There are some teachers especially 5th grade's teachers which only tell the learning material to the students and the students only listen, make a note and memorize the material. This research aims to increase the study performance of student especially on social studies of 5th A grade by using SAVI learning model. This research uses Class Treatment Research method or PTK. This research procedure uses four steps of cycle such as planning, implementating, observing and reflecting step. Data collection technique is cognitive test and data collection instrument is test and observation instrument.

The analysis result shows the study result increasing influences study performance of student. It can be seen from on average percentage result of first cycle is $75 \%$ which means there are 15 of 20 students who can be success. There is $80 \%$ increasing on second cycle which means 16 of 20 students who can be succes on learning. On last cycle, there is significant increasing from the previous cycle about $90 \%$ which means 18 of 20 students can be success. Based on the research result, it can be concluded that the implementation of SAVI learning model can increase the study performance of students on social studies of 5th grade of Al Husna Elementary School (IFDS).

Key words: Study performance, IPS, SAVI learning model

\section{A. PENDAHULUAN}

Keberhasilan proses pembe-
lajaran tidak terlepas dari
kemampuan guru dalam mengem-
bangkan sebuah model-model
pembelajaran yang berorientasi
pada peningkatan intensitas keter-
libatan siswa secara efektif di dalam
proses pembelajaran. Model
pembelajar merupakan kerangka
konseptual berupa pola prosedur
sistematik yang dikembangkan
berdasarkan teori dan digunakan
dalam mengorganisasi proses
belajar mengajar untuk mencapai
tujuan mengajar. ${ }^{1}$

1 Ridwan Abdullah Sani, Inovasi pembelajaran (Jakarta: Bumi Aksara, 2013), 89.
Pengembangan model pembelajaran yang tepat pada dasarnya bertujuan untuk menciptakan kondisi pembelajaran yang memungkinkan siswa dapat belajar secara aktif dan menyenangkan sehingga siswa dapat meraih hasil belajar dan prestasi yang optimal. Oleh karena itu sebagai guru juga harus bisa mengembangkan model-model pembelajaran.

Dengan demikian, agar dapat mengembangkan model pembelajaran yang efektif maka guru harus memiliki pengetahuan yang memadai berkenaan dengan konsepkonsep dan cara pengimplementasian model-model pembelajaran tersebut dalam proses pembelajaran. Proses pembelajaran 
yang efektif memiliki keterkaitan dengan tingkat pemahaman guru terhadap perkembangan kondisikondisi siswa di kelas. Dengan demikian juga pentingnya pemahaman guru terhadap sarana dan fasilitas sekolah yang tersedia, kondisi kelas dan beberapa faktor lain yang memiliki keterkaitan dengan pembelajaran. Tanpa pemahaman terhadap berbagai kondisi ini, model pembelajaran yang dikembangkan oleh guru cenderung tidak dapat meningkatkan peran serta siswa secara optimal dalam proses pembelajaran, dan pada akhirnya tidak dapat memberi sumbangan yang besar terhadap pencapaian hasil belajar.

Salah satu strategi pembelajarannya adalah yang di kenal dengan model pembelajaran SAVI (Somatic, Auditorry, Visualization and Intellectually). Dalam setiap pembelajaran hendaknya tercipta beberapa jenis kegiatan, baik itu mendengar, melihat sampai pada tahap mengkreasi sendiri sebuah karya dengan kemampuan yang dimiliki siswa. Karakteristik dalam model pembelajaran SAVI sudah mewakili semua aktivitas siswa di dalam kegiatan pembelajaran. Karena siswa tidak hanya mendapatkan pengetahuan saja, melainkan juga dapat memahami dan mengalami langsung tentang apa yang telah dipelajari. Model pembelajaran tersebut dapat dikatakan salah satu model pembelajaran yang dapat diterapkan untuk mengatasi permasalahan yang ada di SD Al Husna (IFDS).
Berdasarkan observasi yang dilakukan peneliti, selama ini belum ada yang menerapkan model pembelajaran tersebut di SD Al Husna (IFDS). Sehingga dengan adanya penerapan model pembelajaran ini dapat memberikan perubahan dalam proses pembelajaran sehingga apat meningkatkan prestasi belajar bsiswa SD Al Husna (IFDS) kelas V khususnya pada mata pelajaran IPS.

Mengkaji dari permasalahan di atas, penulis mencoba untuk meneliti tentang penggunaan model pembelajaran SAVI untuk meningkatkan prestasi belajar siswa. Untuk itu penulis mengadakan suatu penelitian tindakan kelas (PTK) dengan judul "Implementasi Model Pembelajaran SAVI Untuk Meningkatkan Prestasi Belajar IPS Pada Siswa Kelas V SD Al Husna Kota Madiun Tahun Pelajaran 2016/2017".

Berdasarkan latar belakang di atas, maka penulis dapat mengidentifikasi permasalahanpermasalahan yang terjadi dalam pembelajaran yang ada di SD Al Husna diuraikan sebagai berikut:

1. Proses pembelajaran masih bersifat konvensional.

2. Guru kurang maksimal dalam mengembangkan model pembelajaran yang inovatif.

3. Kurang mengembangkan pola pikir, keaktifan dan kreativitas siswa selama proses pembelajaran berlangsung.

4. Siswa hanya cenderung menghafalkan konsep konsep yang telah diberikan oleh guru. 
5. Belum menerapkan model pembelajaran SAVI.

Dilihat dari permasalahannya, maka penulis mengajukan rumusan masalah sebagai berikut, "Apakah Implementasi Model Pembelajaran SAVI (Somatic, Auditory, Visualization, And Intelectually) Dapat Meningkatkan Prestasi Belajar IPS Pada Siswa Kelas V SD Al Husna (IFDS) Kecamatan Taman Kota Madiun Tahun Pelajaran 2016/2017?"

\section{B. KAJIAN PUSTAKA}

Arends (dalam Trianto, 2014:54) mengemukakan bahwa model pembelajaran mengacu pada pendekatan pembelajaran yang akan digunakan, termasuk di dalamnya tujuan-tujuan pembelajaran, tahap-tahap dalam kegiatan pembelajaran, lingkungan pembelajaran, dan pengelolaan kelas.

Memilih istilah model pembelajaran berasarkan dua alasan penting, yaitu pertama istilah model mempunyai makna lebih luas daripada strategi, metode, atau prosedur. Kedua, model dapat berfungsi sebagai sarana komunikasi yang penting. Model pembelajaran dapat diklasifikasikan berdasarkan tujuan pembelajaran, sintaksisnya, dan sifat lingkungan belajarnya. Model pembelajaran yang dimaksudkan adalah model pembelajaran yang memiliki kerangka konseptual yang melukiskan prosedur sistematik dalam mengorganisasikan pengalaman belajar.
Menurut Sagala, belajar merupakan komponen ilmu pendidikan yang berkenaan dengan tujuan dan bahan acuan interaksi, baik yang bersifat eksplisit maupun implisit (tersembunyi). ${ }^{2}$ Teori-teori yang dikembangkan dalam komponen ini meliputi antara lain teori tentang tujuan pendidikan, organisasi kurikulum, isi kurikulum, dan modul-modul pengembangan kurikulum.

Djamarah berpendapat bahwa belajar adalah suatu aktifitas yang sadarakan akan tujuan. ${ }^{3}$ Tujuan dalam belajar adalah terjadinya suatu perubahan dalam diri individu. Perubahan dalam arti menuju ke perkembangan pribadi individu seutuhnya. Sejalan dengan itu, Sardiman A.M mengemukakan suatu rumusan bahwa belajar adalah sebagai rangkaian kegiatan jiwa-raga, psikofisik menuju ke perkembangan pribadi manusia seutuhnya., yang menyangkut unur cipta, ras dan karsa, ranah kognitif, afektif dan psikomotor.

Secara harfiah pembelajaran berarti proses, cara, perbuatan mempelajari, dan perbuatan menjadikan orang atau makhluk hidup belajar. ${ }^{4}$

2 Syaiful Sagala, Konsep dan Makna Pembelajaran (Bandung: Alfabeta, 2003).

3 Djamarah Syaiful Bahri, Prestasi Belajar dan Kompetensi Guru (Surabaya, 1994).

4 Naniek Kusumawati, "Pengaruh Model Pembelajaran Kooperatif dengan Snowball Throwing Terhadap Hasil Belajar IPA Pada Siswa Kelas IV SDN Bondrang Kecamatan Sawoo 
Pembelajaran SAVI adalah pembelajaran yang menekankan pada bermaknanya belajar melalui mendengarkan, menyimak, berbicara, presentasi, argumentasi, mengemukakan pendapat, dan menanggapi, serta menggunakan kemampuan berfikir (minds on) untuk meningkatkan konsentrasi pikiran melalui bernalar, menyelidiki, ${ }^{5}$ mengidentifikasi, menemukan, menciptakan, mengkrontruksi, memecahkan masalah dan menerapkan. Sedangkan menurut Meire, belajar menggabungkan gerakan fisik dan intelektual serta menggunakan semua indra yang tujuannya agar dapat mempengaruhi kemajuan belajar, merupakan pengertian dari belajar SAVI. ${ }^{6}$ SAVI merupakan akronim dari Somatic, Auditory, Visual, and Intelectual, yang memiiki arti belajar melalui pemanfaatan gerakan tubuh, (hands on, aktivitas fisik) dimana belajar dimaknai dengan "mengalami" dan

Kabupaten Ponorogo," Ibriez: Jurnal
Kependidikan Dasar Islam Berbasis Sains 2, no. 1 (2017): 1-12.

5 Naniek Kusumawati, "PENGEMBANGAN MEDIA PEMBELAJARAN IPA DENGAN ANIMASI MACROMEDIA FLASH BERBASIS MODEL PENGAJARAN LANGSUNG (DIRECT INSTRUCTION) DI SEKOLAH DASAR," Premiere Educandum: Jurnal Pendidikan Dasar dan Pembelajaran 5, no. 02 (2016).

6 Dave Meier, The Accelerated Learning Handbook: Panduan kreatif dan efektif merancang program pendidikan dan pelatihan (Bandung: Kaifa, 2002).

$\begin{array}{lr}\text { "melakukan" untuk dapat } \\ \text { mengaktualkan } & \text { kemampuan } \\ \text { analisis dalam } & \text { memecahkan } \\ \text { masalah. } & \end{array}$

\section{METODE PENELITIAN}

Penelitian ini menggunakan metode penelitian tindakan kelas. Menurut Arikunto, Penelitian Tindakan Kelas merupakan kegiatan penelitian yang dilakukan di dalam kelas. ${ }^{7}$ Penelitian Tindakan Kelas merupakan salah satu jenis dari pendekatan kualitatif. Penelitian kualitatif dilakukan dengan bentuk siklus atau melingkar (cyclical), bukan linear seperti kuantitatif.

Data yang dikumpulkan adalah melalui catatan observasi dan hasil evaluasi yang dilakukan sejak awal siklus dalam proses penelitian ini. Catatan observasi digunakan untuk mengetahui peningkatan prestasi belajar siswa.

Jenis data yang digunakan dalam penelitian ini adalah kualitatif, dimana dalam penelitian ini peneliti memperoleh data-data berupa keterangan informasi berupa lisan ataupun berupa tulisan. Dalam penelitian ini yang menjadi jenis data penelitian penulis adalah: 1) hasil observasi yang memuat aktivitas siswa maupun guru pada saat pelaksanaan pembelajaran.; 2) prestasi belajar siswa pada latihan soal yang diberikan pada saat pelajaran IPS yaitu diperoleh dari hasil belajar konitif siswa.

\footnotetext{
${ }^{7}$ Suharsimi Arikunto, Prosedur Penelitian Suatu Pendekatan Praktek (Jakarta: Rineka Cipta, 2006).
} 
Sumber data dalam penelitian yang akan dilakukan adalah semua siswa kelas V SD Al Husna (IFDS) ) Kecamatan Taman Kota Madiun Tahun Pelajaran 2016/2017. Jumlah siswa yang akan diteliti sebanyak 20 siswa yang terdiri dari 6 siswa lakilaki dan 14 siswa perempuan. Penelitian ini dilakukan pada kelas V dikarenakan prestasi belajar siswa dalam mat pelajaran IPS (Ilmu Pengetahuan Sosial) masih tergolong rendah karena di kelas ini pembelajarannya masih bersifat konvensional.

Teknik penjaringan data yang digunakan adalah instrumen yang berupa soal tes kognitif yang berisi 20 soal pilihan ganda dan 5 soal uraian. Selain itu data juga di peroleh dari hasil observasi untuk guru maupun siswa itu sendiri. Hal tersebut dilakukan agar peneliti mudah untuk mengamati ada atau tidak adanya peningkatan baik dari hasil belajar maupun peningkatan dalamb kegiatan pembelajaran.

\section{HASIL PENELITIAN}

Pada bagian ini, penulis akan menguraikan mengenai hasil penelitian dari hasil sebelum sampai pada siklus terakhir, ketuntasan nilai yang diperoleh pada siswa kelas VA SD Al Husna (IFDS) mata pelajaran IPS dengan menggunakan model pembelajaran SAVI. Dari observasi yang dilakukan oleh peneliti, dapat diperoleh hasil penelitian dari ketiga siklus yang sudah diterapkan. Dalam penelitian ini di kegiatan pertama yang dilakukan adalah pra siklus. Pra siklus ini diawali kegiatan wawancara dengan guru kelas VA mengenai pembelajaran IPS yang dilakukan selama ini. Selain itu, peneliti juga melakukan wawancara dengan salah satu siswa kelas V. Dari hasil wawancara yang dilakukan dengan guru dan siswa tersebut dapat ditarik kesimpulan bahwa di SD Al Husna ini pembelajaran masih bersifat konvensional. Guru hanya melakukan ceramah dalam kegiatan pembelajaran, sehingga dapat menyebabkan prestasi belajar siswa banyak kurang maksimal karena masih banyak siswa yang nilainya dibawah KKM 75. Pada pra siklus ini diperoleh nilai rata-rata siswa yaitu 61,75 atau sekitar 30\% ketuntasan dari 20 siswa.

Pada tahap selanjutnya, peneliti melakukan penelitian siklus I. Hasil penelitian dari siklus I ini sudah mulai ada peningkatan walaupun masih tergolong sedikit. Pada siklus ini peneliti menerapkan model pembelajaran SAVI. Dalam pelaksanaannya siswa yang berani melakukan tanya jawab dengan guru hanya sebagian kecil saja, karena masih banyak siswa yang kurang memperhatikan ketika guru menjelaskan materi dan menerapkan media pembelajaran, sehingga menyebabkan nilai pada saat evaluasi masih banyak yang belum mengalami ketuntasan belajar. Akan tetapi pada siklus ini sudah mengalami peningkatan dari pembelajaran sebelumnya. Rata-rata nilai yang diperoleh yaitu 75,75 atau 75\% ketuntasan dari 20 siswa kelas V. Pada siklus ini kekurangan guru kurang memusatkan perhatian siswa 
pada saat kegiatan pembelajaran dan penerapan media pembelajaran sehingga masih ada sebagian siswa yang kurang aktif dalam kegiatan pembelajaran.

Selanjutnya yaitu pada tahap siklus II. Pada siklus ini guru menerapkan model pembelajaran SAVI berbantu dengan media gambar yang ditayangkan pada slide. Pada siklus II aktifitas belajar siswa mulai ada peningkatan. Siswa lebih berani melakukan tanya jawab dengan guru. Tidak hanya itu, nilai ketuntasan siswa juga sudah mengalami peningkatan dari pertemuan sebelumnya yaitu 78,25 atau $80 \%$ dari 20 siswa. Akan tetapi meskipun sudah banyak peningkatan masih ada beberapa siswa yang kurang memperhatikan ketika kegiatan pembelajaran berlangsung.

Tahap terakhir yaitu tahap ke III. Dalam tahap ini model pembelajaran SAVI berbantu dengan media pembelajaran berupa video. Dalam kegiatan ini aktifitas belajar siswa mengalami peningkatan yang signifikan daripaa pebelajaran yang sebelumnya. Seluruh siswa dapat memfokuskan perhatiannya selama kegiatan pembelajaran berlangsung utamannya pada saat pemutaran video mengenai konferensi meja bundar (KMB), banyak sisa laki-laki maupun perempuan aktif bertanya. Oleh karena itu, nilai pada saat siklus ke III ini nilai siswa pada saat evaluasi pembelajaran juga tergolong maksimal, hanya ada sebagian kecil yang belum tuntas dalam mengerjakan soal evaluasi.
Rata-rata nilai dalam siklus ini sejumlah 82,00 atau 90\% dari 20 siswa yang tuntas.

\section{E. PEMBAHASAN}

Pada saat siklus I guru tidak memberikan penekanan kepada siswa bahwa siswa yang nilainya kurang harus menghafalkan dan menyebutkannya didepan kelas, sehingga masih banyak siswa yang kurang memperhatikan ketika guru memberikan penjelasan. Guru menyadari bahwa pada siklus II seharusnya siswa harus diberi penekanan agar mau memperhatikan ketika guru memberikan penjelasan dan siswa siap ketika guru melakukan tanya jawab. Hal tersebut dinilai sudah berhasil pada saat siklus II dan siklus III siswa lebih memperhatikan ketika guru memberikan penjelasan, selain itu perubahan media pembelajaran juga mempengaruhi minat belajar siswa. Siswa memperhatikan guru saat menjelaskan materi dengan media tersebut, walaupun masih ada beberapa siswa yang bermain sendiri di belakang. Kemudian pada siklus III guru memberikan media berupa video tentang materi yang dibahas yaitu tentang konferensi meja bundar (KMB), pada saat siklus ini menunjukkan hampir semua siswa memperhatikan dan mayoritas bisa melakukan tanya jawab dengan guru. Oleh karena itu terdapat peningkatan dari tiap siklus, hal tersebut dapat dilihat pada grafik perbandingan penggunaan model pembelajaran SAVI yaitu pada tabel 
5.4 Perbandingan Hasil Belajar pada siklus I, siklus II dan siklus III.
Berdasarkan tabel

Tabel 5.4 Perbandingan Hasil Belajar pada siklus I, siklus II dan siklus III

\begin{tabular}{|c|c|c|c|c|c|c|}
\hline \multirow{2}{*}{ No. } & \multicolumn{2}{|c|}{ Siklus I } & \multicolumn{2}{|c|}{ Siklus II } & \multicolumn{2}{|c|}{ Siklus III } \\
\hline & Skor & Ketuntasan & Skor & Ketuntasan & Skor & Ketuntasan \\
\hline 1 & 85 & $\mathrm{~T}$ & 90 & $\mathrm{~T}$ & 95 & $\mathrm{~T}$ \\
\hline 2 & 75 & $\mathrm{~T}$ & 80 & $\mathrm{~T}$ & 100 & $\mathrm{~T}$ \\
\hline 3 & 80 & $\mathrm{~T}$ & 80 & $\mathrm{~T}$ & 80 & $\mathrm{~T}$ \\
\hline 4 & 75 & $\mathrm{~T}$ & 75 & $\mathrm{~T}$ & 75 & $\mathrm{~T}$ \\
\hline 5 & 80 & $\mathrm{~T}$ & 80 & $\mathrm{~T}$ & 95 & $\mathrm{~T}$ \\
\hline 6 & 70 & $\mathrm{TT}$ & 75 & $\mathrm{~T}$ & 85 & $\mathrm{~T}$ \\
\hline 7 & 80 & $\mathrm{~T}$ & 80 & $\mathrm{~T}$ & 85 & $\mathrm{~T}$ \\
\hline 8 & 70 & $\mathrm{TT}$ & 70 & $\mathrm{TT}$ & 70 & $\mathrm{TT}$ \\
\hline 9 & 80 & $\mathrm{~T}$ & 85 & $\mathrm{~T}$ & 85 & $\mathrm{~T}$ \\
\hline 10 & 65 & TT & 70 & TT & 80 & $\mathrm{~T}$ \\
\hline 11 & 75 & $\mathrm{~T}$ & 80 & $\mathrm{~T}$ & 80 & $\mathrm{~T}$ \\
\hline 12 & 70 & $\mathrm{TT}$ & 70 & $\mathrm{TT}$ & 85 & $\mathrm{~T}$ \\
\hline 13 & 80 & $\mathrm{~T}$ & 80 & $\mathrm{~T}$ & 80 & $\mathrm{~T}$ \\
\hline 14 & 80 & $\mathrm{~T}$ & 80 & $\mathrm{~T}$ & 80 & $\mathrm{~T}$ \\
\hline 15 & 85 & $\mathrm{~T}$ & 85 & $\mathrm{~T}$ & 85 & $\mathrm{~T}$ \\
\hline 16 & 75 & $\mathrm{~T}$ & 80 & $\mathrm{~T}$ & 80 & $\mathrm{~T}$ \\
\hline 17 & 65 & TT & 65 & TT & 60 & TT \\
\hline 18 & 85 & $\mathrm{~T}$ & 85 & $\mathrm{~T}$ & 85 & $\mathrm{~T}$ \\
\hline 19 & 80 & $\mathrm{~T}$ & 80 & $\mathrm{~T}$ & 80 & $\mathrm{~T}$ \\
\hline 20 & 75 & $\mathrm{~T}$ & 75 & $\mathrm{~T}$ & 75 & $\mathrm{~T}$ \\
\hline$\sum$ & 1515 & $\mathrm{~T}=15$ & 1565 & $\mathrm{~T}=16$ & 1640 & $\mathrm{~T}=18$ \\
\hline$\%$ & 75,75 & 75 & 78,25 & 80 & 82 & 90 \\
\hline
\end{tabular}

skor tes pada siklus III mengalami

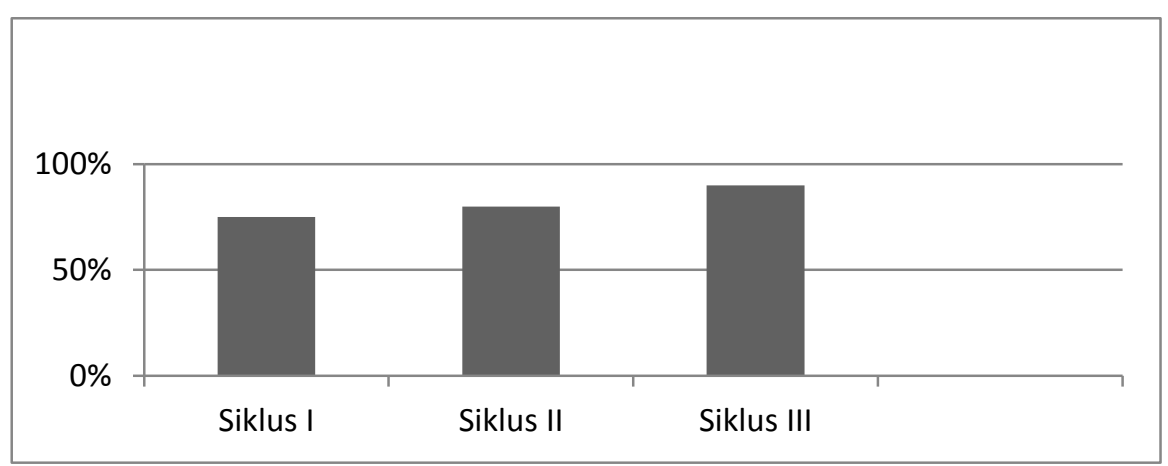

Gambar 5.1 Grafik Perbandingn Ketuntasan Belajar Siswa Kelas V SD Al Husna pada Siklus I, Siklus II dan Siklus III 
peningkatan yang signifikan yaitu 82 dan daya serap klasikal adalah 90\% sehingga hasil belajar siswa telah mencapai ketuntasan belajar yang ditetapkan yaitu rata-rata $>75$ dan daya serap klasikal $90 \%$ hal ini disebabkan keaktifan siswa meningkat pada saat tanya jawab dan mengerjakan tugas individu. Siswa berani bertanya materi yang belum dipahami sebagai persiapan menghadapi kegiatan tanya jawab sehingga jumlah siswa yang tuntas belajar pada siklus III ini meningkat yaitu dari 20 siswa ada 18 siswa yang tuntas dalam kegiatan pembelajaran pada siklus III, sedangkan pada siklus I hanya ada 15 siswa yang tuntas dan pada siklus II ada 16 siswa yang mengalami ketuntasan. Perbandingan tersebut dapat dilihat pada grafik berikut ini:

\section{F. PENUTUP}

Berdasarkan pembahasan hasil penelitian siklus I, siklus II dan siklus III dapat disimpulkan bahwa Implementasi Model Pembelajaran SAVI Dapat Meningkatkan Prestasi Belajar IPS Pada Siswa Kelas V SD Al Husna Kota Madiun Tahun Pelajaran 2016/2017. Hal tersebut ditunjukan dengan presentase ketuntasan dari siklus I yaitu $75 \%$ menjadi $80 \%$ pada siklus II dan $90 \%$ pada siklus III.

Guru yang melaksanakan model pembelajaran SAVI hendaknya pandai memotivasi siswa selain itu guru juga harus aktif membuatkan rangkuman pelajaran yang akan dipelajari siswa dan yang akan menjadi bahan pertanyaan guru.

Kepala sekolah diharapkan lebih memperhatikan kualitas mengajar guru selama ini dan memantau perkembangan hasil belajar siswa yang berdampak pada prestasi belajarnya.

Bagi peneliti lanjut diharapkan bisa memberikan koreksi dan saran mengenai penelitian ini karena peneliti merasa masih banyak kekurangan dalam pembuatannya. Selain itu, peneliti lanjut bisa mengembangkan model pembelajaran SAVI ini agar menggunakan media bantu yang lebih menarik lagi agar siswa lebih maksimal dalam kegiatan pembelajaran.

\section{G. DAFTAR PUSTAKA}

Arikunto, Suharsimi. Prosedur Penelitian Suatu Pendekatan Praktek. Jakarta: Rineka Cipta, 2006.

Bahri, Djamarah Syaiful. Prestasi Belajar dan Kompetensi Guru. Surabaya, 1994.

Kusumawati, Naniek. "Pengaruh Model Pembelajaran Kooperatif dengan Snowball Throwing Terhadap Hasil Belajar IPA Pada Siswa Kelas IV SDN Bondrang Kecamatan Sawoo Kabupaten Ponorogo." Ibriez: Jurnal Kependidikan Dasar Islam Berbasis Sains 2, no. 1 (2017): 1-12.

$\begin{array}{lr}\text { - - "PENGEMBANGAN } & \text { MEDIA } \\ \text { PEMBELAJARAN } & \text { IPA } \\ \text { DENGAN } & \text { ANIMASI } \\ \text { MACROMEDIA } & \text { FLASH }\end{array}$


BERBASIS MODEL

PENGAJARAN LANGSUNG

(DIRECT INSTRUCTION) DI

SEKOLAH DASAR." Premiere

Educandum:

Pendidikan

Pembelajaran 5, no. 02

(2016).

Meier, Dave. The Accelerated Learning Handbook: Panduan kreatif dan efektif merancang program pendidikan dan pelatihan. Bandung: Kaifa, 2002.

Sagala, Syaiful. Konsep dan Makna Pembelajaran. Bandung: Alfabeta, 2003.

Sani, Ridwan Abdullah. Inovasi pembelajaran. Jakarta: Bumi Aksara, 2013. 